NASA Technical Memorandum 100959

AIAA-88-3283

\title{
Recent Advances in Low-Thrust Propulsion Technology
}

\author{
(NASA-TH-1CCS59) RECEAT ADVANCES IN \\ ICH-THRCST PBCELLSICN TECHNCLCEY (NASA)
27 F \\ N88-25260 \\ $\mathrm{CSCL}_{L} 20 \mathrm{C}$ \\ G3/70 $\begin{array}{ll}\text { Onclas } \\ 0148147\end{array}$
}

James R. Stone

Lewis Research Center

Cleveland, Ohio

Prepared for the

24th Joint Propulsion Conference

cosponsored by the AIAA, ASME, SAE, and ASEE

Boston, Massachusetts, July 11-13, 1988 


\title{
RECENT ADVANCES IN LOW-THRUST PROPULSION TECHNOLOGY
}

\author{
James R. Stone \\ National Aeronautics and Space Administration \\ Lewis Research Center \\ Cleveland, Ohio 44135
}

\section{SUMMARY}

The NASA low-thrust propulsion technology program is aimed at providing high performance options to a broad class of near-term and future missions. Major emphases of the program are on storable and hydrogen/oxygen low-thrust chemical, low-power (auxiliary) electrothermal, and high-power electric propulsion. This paper presents the major accomplishments of the program and discusses their impact.

\section{INTRODUCTION}

Low-thrust propulsion has a major impact on the mission performance of essentially all spacecraft and vehicles. On-orbit lifetimes, payloads, and trip times are significantly impacted by low-thrust propulsion performance and integration features. For example, the use of waste gases and water as propellants on Space Station nearly eliminates the requirements for propellant resupply and waste return, resulting in an estimated 10-year savings of $\$ 450,000,000$ to $\$ 690,000,000$ (ref. 1). NASA's low-thrust propulsion program is aimed at providing high performance, or otherwise beneficial, options to both near term and future missions. Major emphasis of the program are on low-thrust chemical, both storables and hydrogen/oxygen (H/O); low-power (auxiliary) electrothermal; and high-power electric propulsion. This paper presents the major recent accomplishments of the program and discusses their impact.

Low-thrust chemical propulsion finds application to a wide class of vehicles including Earth-to-Orbit (ETO) vehicles, Earth-orbit and planetary spacecraft, and large platforms in Earth orbit. On ETO vehicles storable propellants are currently used for on-orbit propulsion, but future systems may take advantage of using primary propellant residuals (hydrogen or hydrocarbons and oxygen) for these functions. Advantages may accrue from both the use of scavenged residuals and the increase in specific impulse $\left(I_{s p}\right)$. Low-thrust storable chemical propulsion is employed on many Earth-orbital and planetary spacecraft. New architectures including propellant resupply create emphas is on extended life as well as increased performance. A storable bi-propellant effort is focused on developing high-temperature thrusters using advanced materials with an order of magnitude life increase which also enable higher specific impulse through reduction of film cooling. Many Earth orbital and planetary spaceraft are equipped with hydrazine thrusters. The hydrazine monopropellant activity has concentrated on long-life thrusters and catalyst beds for possible Space Station application. System studies have examined a wide range of applications for low-thrust H/O propulsion, while the experimental effort has been focused primarily on Space station thrusters capable of long life at an 8:1 mixture ratio. 
Electrothermal propulsion is currently performing North-South stationkeeping (NSSK) on a number of geosynchronous. satellites and. will be used for the Space Station and man-tended platforms. The electrothermal auxiliary propulsion program includes the development of options for high specific impulse and for long life compatibility with multiple propellants. Arcjets are being developed to provide increased life, for high-power geosynchronous satellites. Power electronics technology is required for all of these concepts and is, therefore, an integral part of the program, as it is also in the high-power area.

The growing emphasis on very challenging missions and the anticipated availability of high-power levels in space have led to renewed interest in high-power electric propulsion for interplanetary cargo vehicles and large Earth-orbital platforms. The status of this technology and its application to various missions has been reviewed, leading to identification of the major thruster and system technology issues. Which must be addressed in a focused program in order to assure technology readiness for these missions. Major thrusts of the high-power program are on ion and magnetoplasmadynamic (MPD) propulsion, with exploratory research on advanced concepts, such as electrodeless discharge thrusters.

\section{CHEMICAL}

The low-thrust propulsion program has major thrusts in both the Earth-storable and integrated H/O propulsion areas.

\section{Storable Propellants}

Low-thrust storable monopropellant and bi-propellant propulsion is widely used on a variety of spacecraft, ranging from small satellites to the Space Shuttle... The NASA program has exhibited progress on both types of storable propulsion systems.

Although multipropellant resistojets and hydrogen/oxygen were baselined for Space Station propulsion, the technology of monopropellant hydrazine propulsion was advanced to provide a design. option which might have lower development cost. (although operating costs would be higher due to the requirement for propellant resupply). In order for hydrazine to provide a viable-option for the space station much longer life than had previously been demonstrated was required. Therefore, a cooperative program between the NASA Lewis Research Center and the Rocket Research Company was initiated. A lifetest was conducted on a 22-N hydrazine thruster incorporating the latest technology, long-life catalyst bed. Thịs Rocket Research thruster was tested in the NASA Lewis highaltitude Rocket Engine Test Facility. (fig. 1). Tests were conducted over an operational cycle of both steady-state and pulse firings simulating a possible Space station duty cycle. Tests ran as expected for about $40 \mathrm{hr}$, corresponding to a total impulse of $3.2 \times 10^{6} \mathrm{~N}-\mathrm{s}$. Chamber pressures then began to decrease during long, steady-state runs. After 60..2 hr, tests were terminated because of inadvertent blockage in the propellant injector tube. The source was traced to a barrel of contaminated hydrazine. Even so, this $4.8 \times 1.0^{6} \mathrm{~N}-\mathrm{s}$ total impulise is the greatest reported for small hydrazine rockets (ref. 2):

In the storable propulsion program the operating temperature was significantly increased for nitrogen tetroxide/monomethyl hydrazine $\left(\mathrm{N}_{2} \mathrm{O}_{4} / \mathrm{MMH}\right)$ 
bi-propellant thrusters (ref. 3). NASA Lewis contracted with Aerojet TechSystems Company to develop thrust chambers capable of operating at temperatures as high as $2200{ }^{\circ} \mathrm{C}$ in an oxidizing environment. To obtain this high performance level, a number of thruster material systems was investigated for compatibility with the high-temperature, oxidizing environment (fig. 2 ). Three classes of substrate materials - refractory metals, carbon-carbon composites, and ceramics, and four classes of coating materials - silicides, platinum group metals, Engle-Brewer compounds, and ceramics - were investigated. Various substrate/coating samples were evaluated, leading to the selection of iridium-coated rhenium as the most promising. Two 22-N iridium-coated rhenium thrust chambers with $8: 1$ nozzle expansion ratio were then fabricated by Ultramet using a chemical vapor deposition (CVD) process. The first chamber was then fired for over $8 \mathrm{hr}$ at temperatures from 2040 to $2315^{\circ} \mathrm{C}$ before failure due to oxidative attack from the outside. Changes in test set up and procedures were made to prevent a recurrence of this problem, and the second was then test fired for over $15 \mathrm{hr}$ at temperatures from 1980 to $2260{ }^{\circ} \mathrm{C}$ without failure. This is over a $500{ }^{\circ} \mathrm{C}$ advancement beyond the state-of-the-art (fig. $2(b)$ ). No evidence was seen of any corrosion or attack. This higher temperature capability should allow a 20-sec increase in Isp over state-ofthe-art silicide-coated niobium. The performance will be demonstrated by thrust measurements on a 22-N thruster with a 150:1 area ratio nozzle fabricated from the same materials by the same techniques.

Because of the performance advance described in the preceding paragraph, NASA has selected this technology for the Mariner Mark II Comet Rendezvous/ Asteroid Flyby (CRAF) mission (fig. 2(c)). The reduced propellant mass required $(\sim 600 \mathrm{~kg})$ enables the addition of three experiments to the spacecraft. To assure the readiness of this technology for the mission, the Jet Propulsion Laboratory has contracted with Aerojet for fabrication and test of a 440-N iridium-coated rhenium thruster, with the CVD processing performed by Ultramet. A recent $4 \mathrm{hr}$ test indicated feasibility of the desired performance and lifetime levels (ref. 4 ).

\section{Hydrogen/Oxygen}

The low-thrust hydrogen/oxygen (H/O) effort covers a range of applications including the gaseous H/O for the Space Station and integrated H/O propulsion for Earth-to-orbit vehicles.

Space Station. - The Space Station Advanced Development Program was conducted to, "Provide technology alternatives for the initial and evolutionary Space Station which optimize the system's functional characteristics in terms of performance, cost, and utilization" (ref. 5). Based upon previous studies of manned space stations, two propulsion systems for high and low thrust were investigated (refs. 6 to 8 ). For the high-thrust (110-220 N) function, gaseous $\mathrm{H} / 0$ thrusters were investigated as an alternative to monopropellant hydrazine (refs. 9 to 12). Experimental programs were conducted to examine the technology readiness and life capability of H/O thrusters, and studies were undertaken to ascertain levels of propellants available by integration of the propulsion system with Space Station fluid systems. Thruster hardware development contracts were awarded to Aerojet Techsystems and Bell Aerospace, and Rocketdyne participated through its IRAD program. Initial thruster designs had a goal of greater than $400 \mathrm{sec} I_{\mathrm{sp}}$ and, thus, had mixture ratios from $3: 1$ to $5: 1$. The thrusters are shown in figure 3 . Subsequent studies of propellant availability due to space station fluid management led to the requirement 
to operate at 8:1 mixture ratio with the products of water electrolysis and thus reduced the goal to $346 \mathrm{sec} I_{S p}$. This led: to the need for thruster. design modifications. Time and funding constraints limited the effort, but the Rocketdyne thruster did achieve the life goal of $8.9 \times 10^{6} \mathrm{~N}-\mathrm{s}$, and large total impulses were also demonstrated by Bell and Aerojet. These successful results have led to $H / O$ propulsion being baselined for the high thrust function on the Space Station.

Future launch vehicles. - Studies were conducted that showed great potential for integration of $H / O$ auxiliary propulsion on advanced Earth-to-orbit vehicles (refs. 13 and 14). Unlike previous studies conducted during the Space Transportation System (STS) technology program, these studies have avoided any propellant conditioning requirements and have suggested the development of hardware to use the propellants in the as-delivered state. Thus, the development of 2200 to $4400 \mathrm{~N}$ pressure-fed cryogenic H/O thrusters for the primary Reaction Control System (RCS) is recommended. The thruster must have an extended inlet temperature operating range from cryogenic up to $278^{\circ} \mathrm{K}$ in order to avoid propellant conditioning.

\section{ELECTROTHERMAL}

NASA's electrothermal auxiliary propulsion technology program (ref. 15) includes the development of options for high specific impulse (arcjet), and high thrust-to-power ratio (resistojets). This paper will discuss progress (primarily since publication of ref. 15). on hydrazine arcjets for Earthorbital satellites and platforms with sufficient power, high-performance storable propeliant resistojets for power limited applications, water resistojets for man-tended platforms, and multipropellant resistojets for the Space Station.

\section{Arcjets}

Arcjets offer a very significant performance increase ( $>50$ percent $I_{S p}$ increase) over state-of-the-art auxiliary propulsion, and, thereby, provide significant mass savings for spacecraft with sufficient power on board. Over the past few years, arcjet technology has. advanced from its status in the late 1960's when work was terminated due to insufficient power availability on spacecraft and lack of firm mission requirements to its present near flightready status. Because of the broad range of applications and the potential benefits for a number of NASA and USAF missions, the Air Force. Astronautics Laboratory (AFAL) and NASA Lewis have agreed to pursue a joint research and technology program (ref. 16). The main focus of the NASA program is on low-power thrusters for stationkeeping applications. The power available for auxiliary propulsion on communications satellites is currently limited to about 0.5 to $3.0 \mathrm{~kW}$. Arcjet thrusters operated with storable propellants in that power range should provide significant benefits to the user community. The simplicity of the arcjet system and its elements of commonality. with state-of-the-art hydrazine resistojet systems offer a relatively low risk transition to significantly enhanced performance levels. Successful performance of arcjets in such applications should validate performance and integration approaches and increase the likelihood that the large benefits of arcjets, and other electric thrusters, may be realized for many other missions. 
The modern (1980's) arcjet program was initiated with a 1-kW arcjet, originally designed in the late 1960's for a short flight test using hydrogen propellant (ref. 17). Rapid erosion was observed, and stability problems limited operations, but the performance results indicated that beneficial performance levels could be obtained with storable propellants. Stability and power processor integration issues have been successfully addressed (refs. 18 and 19). Start up and transition to steady-state operation are now repeatable and nondamaging (refs. 20 and 21). To demonstrate starting reliability and the potential for pulsed mode operation, over 11000 pulses ( $3 \mathrm{sec}$ on and $3 \mathrm{sec}$ off) were demonstrated (ref. 22). Life issues have also been successfully addressed, (refs. 20, 21 and 23) indicating the potential for necessary mission life. Specific impulse as high as $729 \mathrm{sec}$ was obtained with hydrazine in a conventional constricted arc design, (refs. 24 and 25) and other tests with mixed gas propellants (ref. 26) confirm the high specific impulse potential of this approach. However, the results from testing an approach incorporating a mixing chamber intended to improve efficiency gave relatively poor performance (ref. 27). Since the performance and life of hydrazine propulsion systems, including arcjets, are dependent on the catalytic gas generator, an experiment was conducted to determine the variation in output composition as a function of time (ref. 28). In $28 \mathrm{hr}$ of testing over a 3-month interval, the catalyst bed efficiency increased rapidly with increasing temperature (which is, in turn, flow dependent) for temperatures below $450{ }^{\circ} \mathrm{C}$ and remained essentially constant, with about 11 percent $\mathrm{NH}_{3}$ at higher temperatures.

Based on these successes, a long-term, autonomous cyclic life test was initiated (ref. 29) and recently successfully completed (ref. 30). Over 500 cycles of $2-h r$ duration were performed at a specific impulse of about $450 \mathrm{sec}$ and about 1.2-kW power level. The life test thruster is shown in figure 4 , and its specific impulse versus thrust-to-power ratio characteristics are shown in figure 5. Typical performance histories of several cycles are shown in figure 6 . No significant changes were seen throughout the test. At the design current of $11 \mathrm{~A}$, the specific impulse variation was less than 2 percent over the duration of the test, while the voltage rose gradually to 110 percent of its original $101 \mathrm{~V}$. The test was voluntarily terminated with the total firing time simulating 20 years of service on a communications satellite. The electrodes were still in excellent condition (fig. 7), and only $6 \mathrm{mg}$ of mass loss occurred from the cathode.

After the successful demonstration of performance and life, it was appropriate to initiate investigation of those thruster/spacecraft integration characteristics required to enable the use of arcjets on operational spacecraft. A preflight development effort has been initiated to minimize the risks associated with flight testing of an arcjet to facilitate the achievement of operational.status. Areas of concern are thruster and power processor mass, thermal loading, exhaust plume interaction, and both conducted and radiated electromagnetic interference. Thermal loading is a function of individual system design and plume characteristics. In terms of heat conduction to the spacecraft, the power processor load is the most significant, and efforts to reduce this load by improving efficiency are underway. Electromagnetic interference (EMI) concerns are being addressed in ground testing, but experience based on space tests with more highly ionized plumes indicates that any problems should be manageable (ref. 31). Experiments have been conducted in a large vacuum facility to determine arcjet plume plasma characteristics using Langmuir probes, and the plumes were found to be less than 1 percent ionized (refs. 32 and 33 ). 
Based on these results, an analytical study has been conducted of the communications impact of a low-power arcjet thruster by modeling the plume as a plasma slab. Except for propagation paths which pass very near the arcjet thruster, the impacts of transmission appear to be minimal (ref. 34).

\section{Resistojets}

High-performance storable resistojets. - To advance storable propellant resistojets beyond the current state-of-the-art 295-sec mission average specific impulse, several efforts have been undertaken. Improved heat exchanger performance, longer-life higher-temperature heaters, (ref. 35) and improved nozzle performance (refs. 36 and 37) are being sought. The importance of high quality facilities for evaluating resistojet performance has been demonstrated (refs. 38 and 39). It has been shown that increasing facility background pressure increases the convective heat losses from the engine, resulting in decreased performance, as shown in figure 8 .

Water resistojets. - Interest in water resistojets developed as a spin-off to the Space station multipropellant resistojet development. For man-tended, shuttle-serviced platforms such as the Industrial space Facility (ISF), ease and safety of propellant resupply and ground handling operations are critical issues, which leads to the interest in water as a propellant. With a resistojet capable of steam operation already being developed for the Space station, water resistojets were baselined for the ISF (ref. 40). This necessitated the development of a zero-gravity steam generator when it was determined that available steam generators, such as that developed for the Manned Orbiting Laboratory, did not perform stably and reliably and that operation of the Space Station resistojet with liquid water feed could be quite unstable. (ref. 41). A cyclone steam generator (fig. 9) was developed after study of a number of boiler concepts studied for space power system applications (ref. 42). Further development of this concept led to an integrated vaporizer/resistojet utilizing a single heater as described more fully in reference 43. This concept is shown in figure 10; the liquid water is swirled to the outer wall and boiled by heat radiated from the central heater which also heats the resistojet by conduction. Losses are reduced since the outer wall operates at temperatures below saturation. This design also overcomes the many stability and phase separation problems typically encountered in zero-gravity boilers (ref. 42 ).

Space Station. - As previously mentioned, multipropellant resistojets have been baselined on the Space Station. The requirements for Space Station propulsion are quite different from most other propulsion applications in that long life and integration features are much more important than performance (ref. 44). Utilizing Space Station wastes as propellant minimizes resupply requirements, and may eliminate the need to return some wastes. Grainstabilized platinum was selected as the thruster material following a series of propellant/material compatibility tests (refs. 45 and 46 ) and confirmed by a 2000-hr cyclic life test of a laboratory model thruster (ref. 47). Performance characteristics on a wide range of possible propellants have been obtained on an engineering model thruster, (ref. 41) and long term life tests are underway; $6100 \mathrm{hr}$ and 83 thermal cycles have been demonstrated (ref. 48). A power controller was developed to enable the thruster to operate on the high frequency power to be provided on the space station (ref. 49). To facilitate the integration of this technology on the space station, propellant and feed 
systems options were assessed (ref. 50) and interfaces defined (ref. 51). The exhaust plumes of the thrusters are of concern because of potential effects on sensors and experiments and potential attenuation of signals propagating through the plume. Analytical and experimental techniques have been developed, (ref. 52) and a preliminary assessment made of the effect of nozzle geometry on plume characteristics (ref. 53).

\section{HIGH-POWER ELECTRIC}

The growing emphasis on very challenging missions and the anticipated availability of high-power levels in space have led to renewed interest in high-power electric propulsion (ref. 54). This section reviews the status of high-power electric propulsion technology and its applicability to various missions.

The National Commission on Space advocated a number of challenging missions, such as a return to the Moon, unmanned and manned exploration of Mars and its moons, and unmanned scientific exploration of the rest of the solar system (ref. 55). Many of these missions would be enhanced, and some would be enabled by high specific impulse electric propulsion. To perform the challenging future missions, high-power and high specific impulse systems will be required. Candidate systems include ion (refs. 56 to 64) and magnetoplasmadynamic (MPD) engines, (refs. 65 to 72) with electrodeless approaches

(refs. 73 to 77 ) representing a. longer term possibility. To perform these challenging future missions, the total impulse capability must be advanced the currently demonstrated $10^{6} \mathrm{~N}-\mathrm{s}$ for both ion and MPD engines to at least $10^{8} \mathrm{~N}-\mathrm{s}$. There are also many potential applications for high I $_{\text {sp }}$ electric propulsion at the tens of kilowatts available from large solar power systems. For example, a USAF study has shown a high potential payoff for a solar electric orbit transfer vehicle for the delivery of satellite constellations to their operational orbits (ref. 78 ).

\section{Ion}

Ion propulsion is the highest specific impulse option with sufficient technical maturity to be considered for near-term applications. Benefits have been identified for both primary (refs. 57 and 78) and auxiliary propulsion (refs. 79 and 80). The technology program is, therefore, focussed on power levels appropriate for both solar (primary and auxiliary) and nuclear powered (primary) applications.

An extended test was conducted of a $30-\mathrm{cm}$ diameter, divergent-field ion thruster (fig. 11) using xenon propellant at a 10-kW power level (ref. 65). $567 \mathrm{hr}$ of testing were completed at a beam current of $5 \mathrm{~A}$. Primary wear mechanisms were identified so that long-life, high-power engines can be developed. Three mechanisms were identified: nonuniform erosion on the upstream side of the baffle; oxidation, deformation, and cracking of the tantalum cathode tube, probably due to cold startup, but possibly related to the high partial pressure of water in residual facility gases; and charge exchange ion erosion of the accelerator grid. Screen grid erosion, which was the lifelimiting mechanism for $3-\mathrm{kW}$ mercury ion thrusters, was reduced greatly (fig. 12). Based on the experimentally obtained erosion data, the screen grid life is projected to be over $7000 \mathrm{hr}$. 
Scaling of ion engines to larger size is desirable for nuclear class power levels, and preliminary results have been obtained (ref. 66). Laboratory and engineering model $30-\mathrm{cm}$ diameter thrusters were operated with xenon propellant over a power range from 2 to $20 \mathrm{~kW}$. Preliminary performance results were also obtained for laboratory model $50-\mathrm{cm}$ diameter cusp- and divergent-field thrusters operating with both $30-\mathrm{cm}$ and $50-\mathrm{cm}$ diameter ion optics over the 10-kW range. These results represent the first output of a program aimed at developing scaling technology and, ultimately, nuclear-class ion engine systems.

\section{Magnetop lasmadynamic}

Both self-field and applied field (fig. 13) MPD thrusters are being investigated. Much of the recent research into the fundamentals of self-field thrusters has been conducted using pulsed-mode rather than continuous operation (refs. 66,67 , and 71 ). A summary has recently been completed on the performance and life characteristics of quasi-steady state and continuous MPD thrusters (ref. 70). High-efficiency is required and promising results have been reported for hydrogen and lithium propellants $(0.43$ and 0.69 efficiency, respectively). Other propellants show efficiencies in the 0.10 to 0.35 range at 1000 to $4500 \mathrm{~s}$ specific impulse. High thermal efficiencies at megawatt power levels in pulsed operation and low electrode erosion rates have recently been reported, indicating that MPD thrusters may be developed with sufficient life and performance for extended, very high-power missions. The feasibility of high-power, continuous operation has recently been demonstrated at NASA Lewis, where an MPD arc thruster has been operated at over $100 \mathrm{~kW}$ in both self and applied field (0.3 tesla) modes (fig. 14) (ref. 81).

\section{Electrodeless Discharge Thrusters}

Electrodeless thruster concepts offer the potential for very high energy coupling efficiency, and are, therefore, of great interest for high-power systems (ref. 82). Electromagnetic energy is applied at radio through microwave frequencies to provide electrothermal, cyclotron resonance, or ion-cyclotron resonance heating of the propellant. Limitations imposed by electrode erosion in other electric thrusters may be avoided. NASA Lewis is evaluating the microwave electrothermal thruster, which absorbs the applied power in a plasma discharge and heats the gas propellant by high pressure thermalization. Advantages include high-efficiency power absorption and conversion, high-power density, and external control of discharge location, shape, and volume.

\section{CONCLUDING REMARKS}

The NASA low-thrust propulsion program is developing the technology to provide significant benefits to a wide class of vehicles and missions. Significant advances have been made in low-thrust chemical propulsion, both storable and hydrogen/oxygen, in low-power (auxiliary) electric propulsion, and in high-power (primary) electric propulsion technology at power levels appropriate to large solar and nuclear systems. 


\section{REFERENCES}

1. Minutes of the Space Station Control Board, NASA Johnson Space Center, Houston, TX, April 24, 1986.

2. Meng, P.R., Schneider, S.J., Morgan, C.J., Jones, R. E., and Pah1, D.A., "A Life Test of a 22 Newton ( 5 l bf ) Hydrazine Rocket," JANNAF Propulsion Conference, San Diego, CA, December 1987 (also NASA TM-100232).

3. Whalen, M.V., Lansaw, P.T., and Wooten, J.R.: "High Temperature, Oxidation Resistant Thrusters," JANNAF Propulsion Conference, San Diego, CA, December 1987.

4. Wooten, J.R., Aerojet TechSystems Co., Sacramento, CA, Personal Communication, 1988.

5. "Space Station Program Description Document, Book 1, Introduction and Summary," NASA TM-86652-BK-1, 1984.

6. Jones, R.E.., "High and Low-Thrust Propulsion Systems for Space Station," AIAA Paper 87-0398, January 1987.

7. Jones, R.E., Meng, P.R., Schneider, S.J. Sovey, J.S., and Tacina, R.R., "Space Station Propulsion System Technology," Acta Astronautica, Vol. i5. No. 9, September 1987.

8. Jones, R.E., Morren, W.E., Sovey, J.S., and Tacina, R.R., "Space Station Propulsion," JANNAF Propulsion Conference, San Diego, CA, December 1987 (a) SO NASA TM-100216).

9. Heckert, B.J. et al, "25 lbf Gaseous Oxygen Gaseous Hydrogen Thruster for Space Station. Application," 1986 JANNAF Propulsion Meeting, Vol. 1, Strange, K.L., and Eggleston, D.S., Eds., CPIA-PUBL-455-VOL.-1, Chemical Propulsion Information Agency, 1986, pp. 539-546.

10. Robinson; P.J., and Rosenthal, S.E., "A Proven 25-1bf $\mathrm{H}_{2} / \mathrm{O}_{2}$ Thruster for Space Station Auxiliary Propulsion," AIAA Paper 86-1560, June 1.986.

11. Senneff, J.M., and Richter, G.P., "A Long-Life 50 lbf $\mathrm{H}_{2} \mathrm{IO}_{2}$ Thruster for Space Station Auxiliary Propulsion," AIAA Paper 86-1404, June 1986.

12. Richter, G.P., and Price, H.G., "Proven, Long-Life Hydrogen/Oxygen Thrust Chambers for Space Station Propulsion," 1986 JANNAF Propulsion Meeting, Vol. 1, Strange, K. L., and Eggleston, D. S., Eds., CPIA-PUBL-455-VOL-1, Chemical Propulsion Information Agency, 1986, pp. 547-564 (also NASA TM-88822).

13. Schneider, S.J., "Auxiliary Propulsion Technology for Advanced Earth-to-Orbit Vehicles," JANNAF Propulsion Conference, San Diego, CA, December 1987 (al so NASA TM-100237).

14. Schneider, S.J., and Reed, B.D., "Weight Savings in Aerospace Vehicles through Propellant Scavenging," SAWE Paper 1818 (Index Category No. 24), Presented at 47th Annual Conference of the Society of Allied Weight Engineers, Inc., Plymouth, MI, May 1988. 
15. Stone, J. R., "NASA Electrothermal Auxiliary Propulsion Program," AIAA Paper 86-1703, June 1986.

16. Stone, J.R., and Huston, E.S., "The NASA/USAF Arcjet Research and Technology Program," AIAA-Paper 87-1946, June-July 1987.

17. Nakanishi, S., "Performance Evaluation of a 1-kW Arcjet Thruster," AIAA Paper 85-2033, September-October 1985.

18. Curran, F. M., and Nakanishi, S., "Low-Power dc Arcjet Operation with Hydrogen/Nitrogen Propellant Mixtures," AIAA Paper 86-1505, June 1986.

19. Gruber, R.P., "Power Electronics for a 1-kW Arcjet Thruster," AIAA Paper 86-1507, June 1986.

20. Curran, F.M., and Haag, T.W., "Arcjet Component Conditions through a Multistart Test, "AIAA Paper 87-1060, May 1987.

21. Haag, T.W., and Curran, F.M., "Arcjet Starting Reliability: a Multistart Test on Hydrogen/Nitrogen Mixtures," AIAA Paper 86-1061, May 1987.

22. Sarmiento, C. J., and Gruber, R. P., "Low-Power Arcjet Thruster Pulse Ignition," AIAA Paper 87-1951, June-July : 1987.

23. Simon, M.A., Knowles, S.C., Curran, F.M., and Hardy, T.L., "Low-Power Arcjet Life Issues," AIAA Paper 87-1059, May 1987.

24. Knowles, S.C., "Arcjet Thruster Research and Technology - Phase I Final Report," Rocket Research Co., Redmond, WA (Contract NAS3-24631), August 1987 (NASA CR-182107).

25. Knowles, S.C., Smith, W., W., Curran, F.M.., and Haag, T.W., "Performance Characterization of a Low-Power Hydrazine Arcjet," AIAA Paper 87-1057. May 1987.

26. Hardy, T.L., and Curran, F.M., "Low-Power dc Arcjet Operation with Hydrogen/Nitrogen/Ammonia Mixtures," AIAA Paper 87-1948, June-July 1987.

27. Make1, D.B., and Cann, G.L., "Arcjet Research and Technology," Aerojet Techsystems, Company, Sacramento, CA (Contract NAS3-24842), February 1988, (NASA CR-180865).

28. Curran, F.M., and Whalen, M.V., "In-Situ Analysis of Hydrazine Decomposition Products," AIAA Paper 87-2122, June-July 1987.

29. Curran, F.M., Hardy, T.L., and Haag, T.W., "A Low-Power Arcjet Cyclic Lifetest," JANNAF Propulsion Conference, San Diego, CA, December 1987 (al so NASA TM-100233).

30. Curran, F.M., and Haag, T.W., "An Extended Life and Performance Test of a Low-Power Arcjet," AIAA Paper 88-3106, July 1988. 
31. Sovey, J.S., Zana, L.M., and Knowles, S.C., "Electromagnetic Emissions Experiences Using Electric Propulsion Systems - A Summary," AIAA Paper 87-2028, June-Juiy 1987.

32. Zana, L.M., "Langmuir Probe Surveys of an Arcjet Exhaust," AIAA Paper 87-1950, June-July 1987.

33. Carney, L.M., "An Experimental Investigation of an Arcjet Thruster Exhaust Using Langmuir Probes," NASA TM-100258, April 1988.

34. Carney, L.M., "Evaluation of the Communications Impact of a Low-Power Arcjet Thruster," AIAA Paper 88-3105, July 1988.

35 Barr, F.A., and Page, R.J., "Slip Casting and Extruding Shapes of Rhenium with Metal Oxide Additives, II - Development of Grain Stabilized Rhenium Parts for Resistojets," The R.J. Page Co., Santa Ana, CA (Contract NAS3-24651), November 1987 (NASA CR-180851).

36. Grisnik, S.P., Smith, T.A., and Saltz, L.E., "Experimental Study of Low Reynolds Number Nozzles," AIAA Paper 87-0092, May 1987.

37. Whalen, M.V., "Low Reynolds Number Nozzle Flow Study," NASA TM-100130, July 1987.

38. Manzella, D.H., DeWitt, K.J., Kieth, T.G., and Penko, P.F., "The Effect of Ambient Pressure on the Performance of a Resistojet," AIAA Paper 87-0991, May 1987.

39. Manzella, D.H., Penko, P.F., DeWitt, K.J., and Kieth, T.G., "An Experimental Investigation of the Effect of a Test Cell Pressure on the Performance of Resistojets," AIAA Paper 88-3287, July 1988.

40. Louviere, A.J., Jones, R.E., Morren, W.E., and Sovey, J.S., "WaterPropellant Resistojets for Man-Tended Platforms," IAF Paper 87-2519, October 1987.

41. Morren, W.E., Hay, S.S., Haag, T.W., and Sovey, J.S., "Preliminary Performance Characterization on an Engineering Model Multi-propellant Resistojet for Space Station Application," AIAA Paper 87-2120, June-July 1987.

42. Stone, J.R., Gray, V.H., and Gutierrez, O.A., "Forced-Flow Once-Through Boilers - NASA Research," NASA SP-369, 1975.

43. Morren, W.E., and Stone, J.R., "Development of a Liquid-Fed Water Resistojet," AIAA Paper 88-3288, July 1988.

44. Pugmire, T.K., Cann, G.L., Heckert, B., and Sovey, J.S., "A 10,000 hr Life Multipropellant Engine for Space Station Application," AIAA Paper 86-1043, June 1986.

45. Whalen, M.V., and Grisnik, S.P., "Compatibility of Grain Stabilized Platinum with Candidate Propellants for Resistojets," AIAA Paper 85-2014, September 1985.

46. Whalen, M.V., and Nathal, M.V., "Compatibility of Dispersion-Strengthened Platinum with Resistojet Propellants," NASA TP-2765, October 1987. 
47. Morren, W.E., and Sovey, J.S., "2000-hr Cyclic Endurance Test of a Laboratory Model Multi-propellant Resistojet," AIAA Paper 87-0993, May 1987.

48. Slutz, R.J., Personal Communication, NASA Lewis Research Center, Cleveland, $\mathrm{OH}$, June 1988.

49. Gruber, R.P., "Resistojet Control and Power for High Frequency Buses," AIAA Paper 87-0994, May 1987.

50. Bader, C.H., "Potential Propellant Storage and Feed Systems for Space Station Resistojet Propulsion Options," Sverdrup-Technology, Inc., Cleveland, $\mathrm{OH}$ (Contract NAS3-24105), January 1987, (NASA CR-179457).

51. Heckert, B.J., "Space Station Resistojet System Requirements and Interface Definition Study," Report No. RI/RD87-109, Rocketdyne Division, Rockwell International Corp., Canoga Park, CA (Contract NAS3-24658), February 1987 (NASA CR-179581).

52. Zana, L.M., Hoffman, D.J., Breyley, L.R., and Serafini, J.S., "An Analytical and Experimental Investigation of Resistojet Plumes," AIAA Paper 87-0399, January 1987.

53. Breyley, L.R., Hoffman, D.J., Zana, L.M., and Serafini, J.S., "Effect of Nozzle Geometry on the Resistojet Exhaust Plume," AIAA Paper 87-2121, June-July 1987.

54. Byers, D.C., and Wasel, R.A., "The NASA Electric Propulsion Program," AIAA Paper 87-1098, May 1987.

55. National Commission on Space, "Pioneering the Space Frontier," Bantam Books, NY, June 1986.

56. Hardy, T.L., Rawlin, V.K., and Patterson, M.J., "Electric Propulsion Options for the SP-100 Reference Mission," NASA TM-88919, Presented at 4th Symposium on Space Nuclear Power Systems, Albuquerque, NM, January 1987.

57. Galecki, D.L., and Patterson, M.J., "Nuclear Powered Mars Cargo Transport Using Advanced Ion Propulsion," AIAA Paper 87-1903, June-July 1987.

58. Beattie, J.R., Matossian, J.N., and Robson, R.R., "Status of Xenon Ion Propulsion," AIAA Paper 87-1003, May 1987.

59. Matossian, J.N., and Beattie, J.R., "Plasma Properties in Electron Bombardment Ion Thrusters," AIAA Paper 87-1076, May 1987.

60. Rawlin, V.K., "Internal Erosion Rates of a 10-kW Xenon Ion Thruster," AIAA Paper 88-2192, July 1988.

61. Patterson, M.J., and Rawlin, V.K., "Performance of 10-kW Class Xenon Ion Thrusters," AIAA Paper 88-2914, July 1988.

62. Shimada, S., Takegahara, H., Kimura, H., and Kajiwara, K., "Ion Engine System for North-South Stationkeeping of Engineering Test Satellite VI," AIAA Paper 87-1005, May 1987. 
63. Aston, G., Brophy, J.R., Garner, C.E., and Pless, L.C., "Operating Characteristics of a 10-kW Xenon Ion Propulsion Module," AIAA Paper 87-1006, May 1987.

64. Wilbur, P.J., and Han, J.Z., "Constrained Sheath Optics for High-Thrust Density Low Specific Impulse Thruster Operation," AIAA Paper 87-1073, May 1987.

65. Sovey, J.S., and Mantenieks, M.A., "Performance and Lifetime Assessment of MPD Thruster Technology - 1988," AIAA Paper 88-3211, July 1988.

66. Gilland, J., Kelly, A.N., and Jahn, R.G., "MPD Thruster Scaling Research," AIAA Paper 87-0997, May 1987.

67. Polk, J.E., Kelly, A.J., and Jahn, R.G., "MPD Thruster Erosion Research," AIAA Paper 87-0999, May 1987.

68. Meyers, R., Kelly, A.J., and Jahn, R.G., "Electrothermal-Electromagnetic Hybrid Thruster Research," AIAA Paper 87-1018, May 1987.

69. Kurtz, H.L., Auweter-Kurtz, M., Merke, W., and Schrade, H.O., "Experimental MPD Thruster Investigations," AIAA Paper 87-1019, May 1987.

70. King, D.Q., "Design and Operation of a 100-kW, Subscale MPD Engine," AIAA Paper 87-1020, May 1987.

71. Choueri, E.Y., Kelly, A.J., and Jahn, R.G., "Instabilities in the MPD Thruster Plasma," AIAA Paper 87-1067, May 1987.

72. Auweter-Kurtz, M., Kurtz, H.L., Schrade, H.O., and Sleziona, P.C., "Numerical Modeling of the Flow Discharge in MPD Thrusters," AIAA Paper 87-1091, May 1987.

73. Whitehair, S., Asmussen, J., and Nakanishi, S., "Microwave Electrothermal Thruster Performance on Helium Gas," J. Propulsion and Power, Vol. 3, No. 2, March-April 1987, pp. 136-144.

74. Morin, T.J., and Hawley, M.C., "The Efficacy of Heating Low-Pressure $\mathrm{H}_{2}$ in a Microwave Discharge," Plasma Chemistry and Plasma Processing,

Vol. 7, No. 2, 1987.

75. Hawley, M.C., Asmussen, J., Filpus, J.W., Whitehair, S., and Chapman, R., "A Review of Research and Development on the Microwave-Plasma Electrothermal Rocket," AIAA Paper 87-1011, May 1987.

76. Frasch, L.L., Griffin, J.M., and Asmussen, J., "An Analysis of Electromagnetic Coupling and Eigenfrequencies for Microwave Electrothermal Thruster Discharges," AIAA Paper 87-1012, May 1987.

77. Filpus, J.W., and Hawley, M.C., "A Computer Model for The Recombination Zone of a Microwave-Plasma Electrothermal Rocket," AIAA Paper 87-1014, May 1987.

78. Sponable, J.M., and Penn, J.P., "An Electric Orbit Transfer Vehicle for Delivery of NAVSTAR Satellites," AIAA Paper 87-0985, May 1987. 
79. Schreib, R., "Utility of Xenon Ion Stationkeeping," AIAA Paper 86-1849, June 1986.

80. Power, J.L., Ignaczak, L.R., Collett, C.R., and Beaver, D.R., "Ion Auxiliary Propulsion System (IAPS) 8-cm Mercury Ion Thruster Flight Test Status and Supporting Ground Tests," AIAA Paper 85-2025, October 1985.

81. Sovey, J.S., Personal Communication, NASA Lewis Research Center, Cleveland, OH, May 1988.

82. Power, J.L., Personal Communication, NASA Lewis Research Center, Cleveland, $\mathrm{OH}$, June 1988.

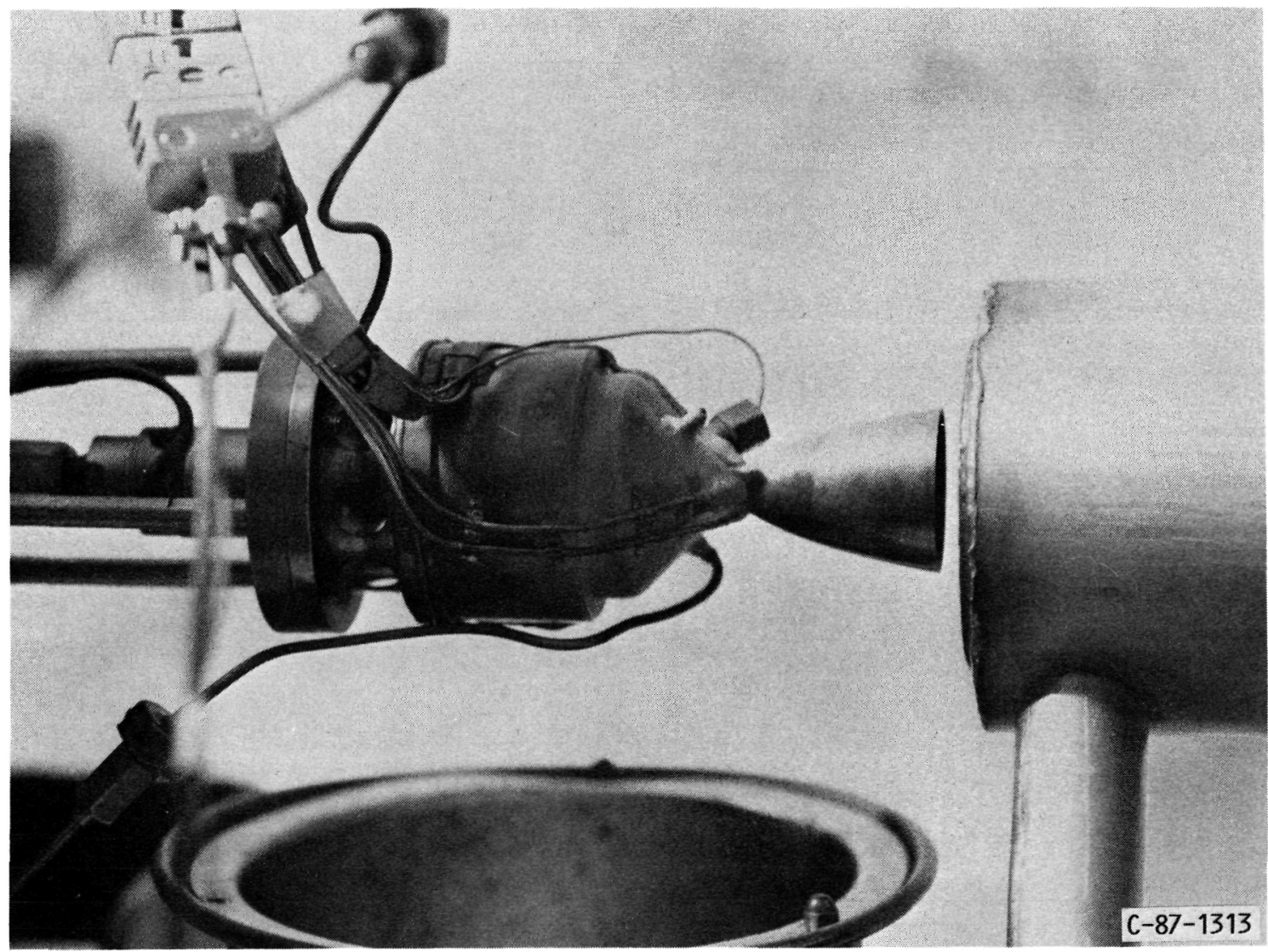

FIGURE 1. - 22-N HYDRAZINE MONOPROPELLANT THRUSTER FIRING IN NASA LEWIS HIGH-ALTITUDE FACILITY. 


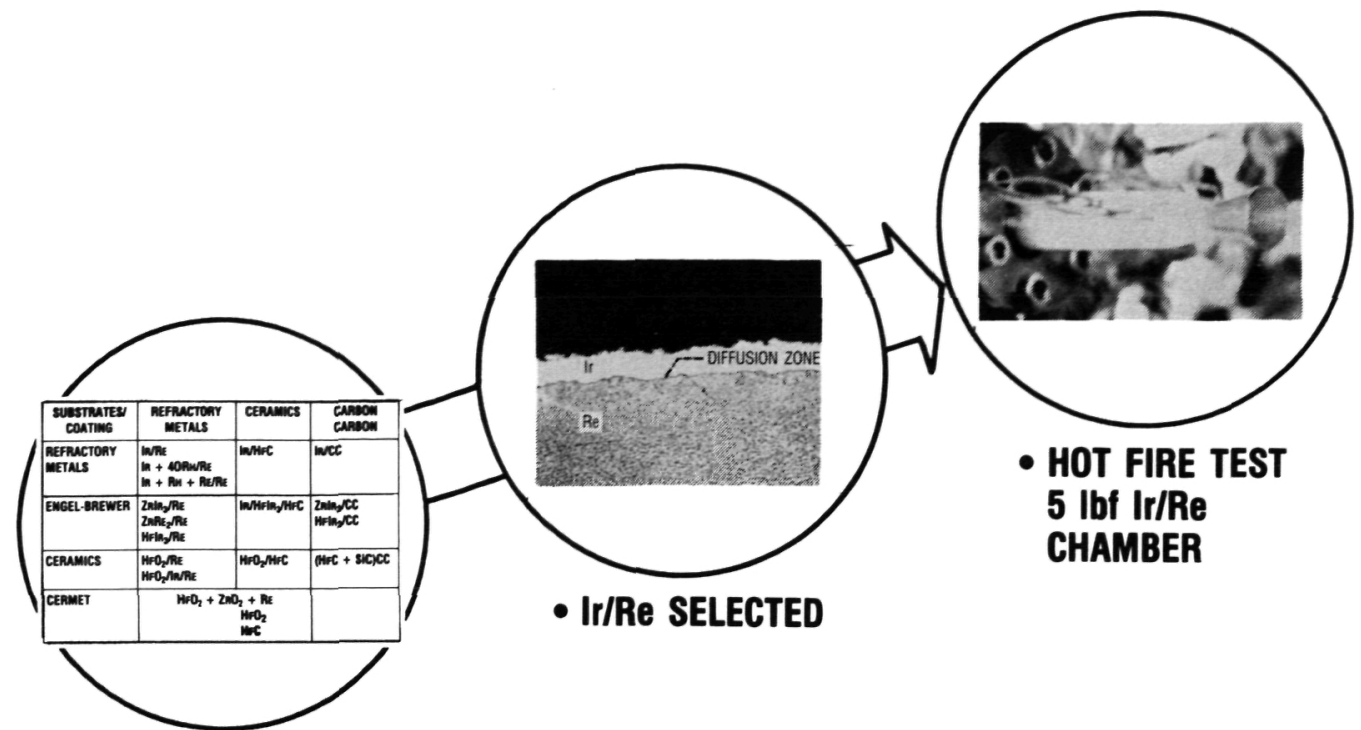

- SUBSTRATE/COATING

COUPLES EVALUATED

CD-87-29558

(a) APPROACH.

FIGURE 2. - ADVANCED CHAMBER TECHNOLOGY.

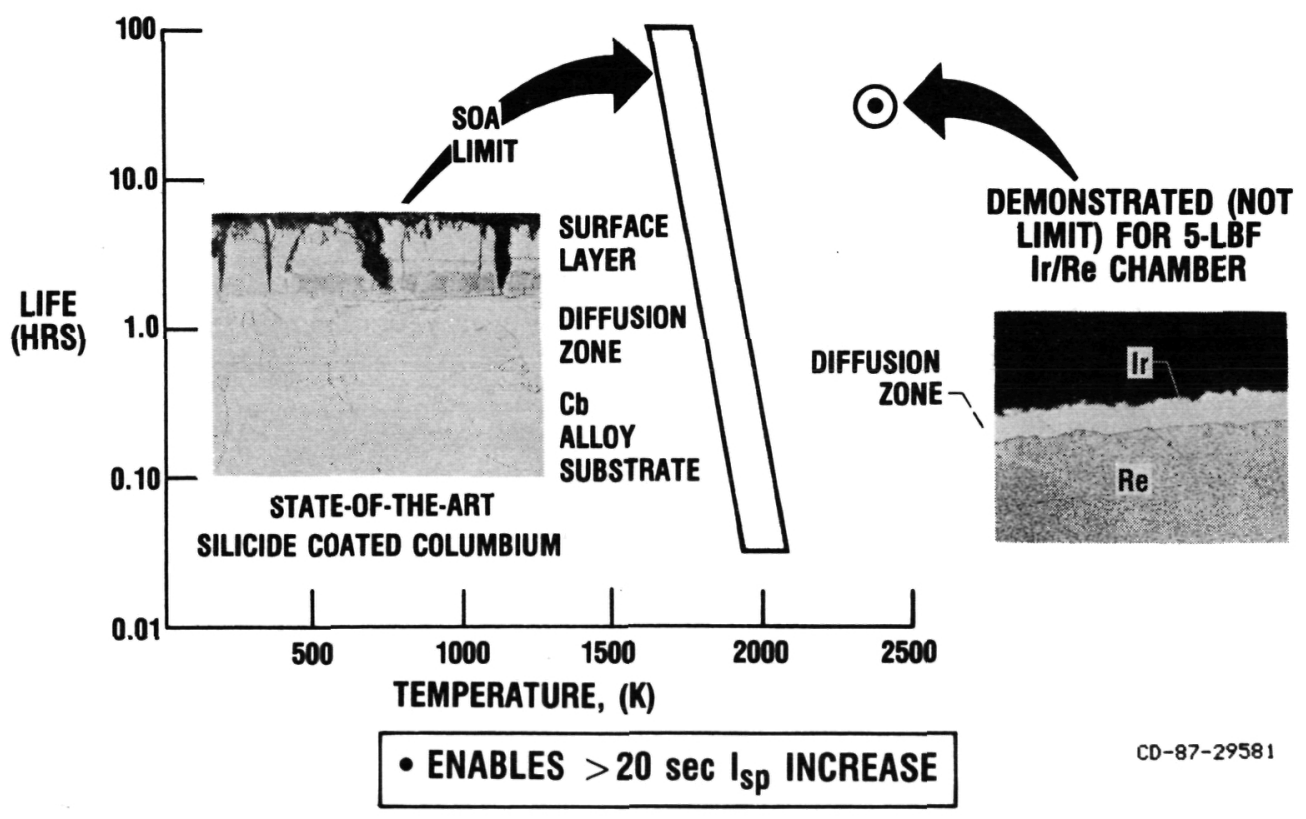

(b) LIFE VERSUS TEMPERATURE FOR NTO/MMH.

FIGURE 2. - CONTINUED. 
- TECHNOLOGY SELECTED FOR MMII-CRAF

- REDUCED PROPELLANT MASS $\sim 600 \mathrm{~kg}$

- ENABLES ADDITION OF THREE EXPERIMENTS TO MISSION

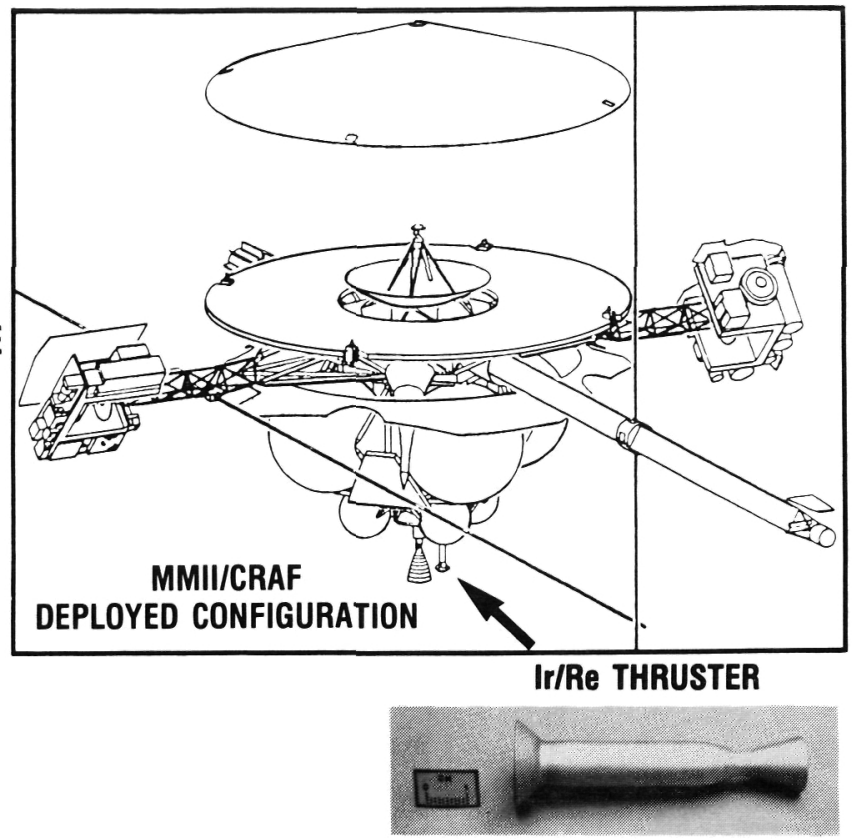

(c) IMPACT.

FIGURE 2. - CONCLUDED.

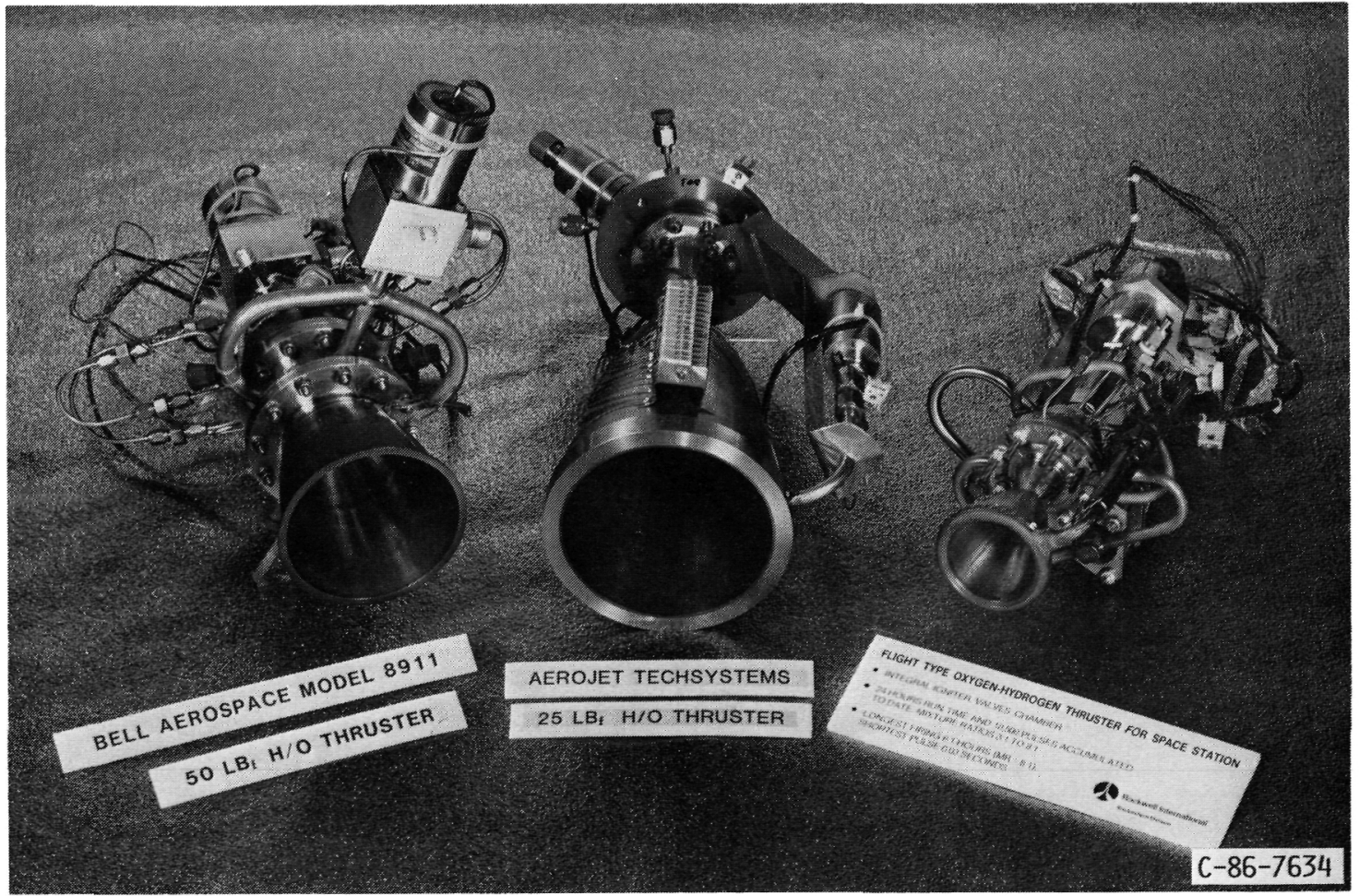

FIGURE 3. - SPACE STATION HYDROGEN/OXYGEN THRUSTERS. 


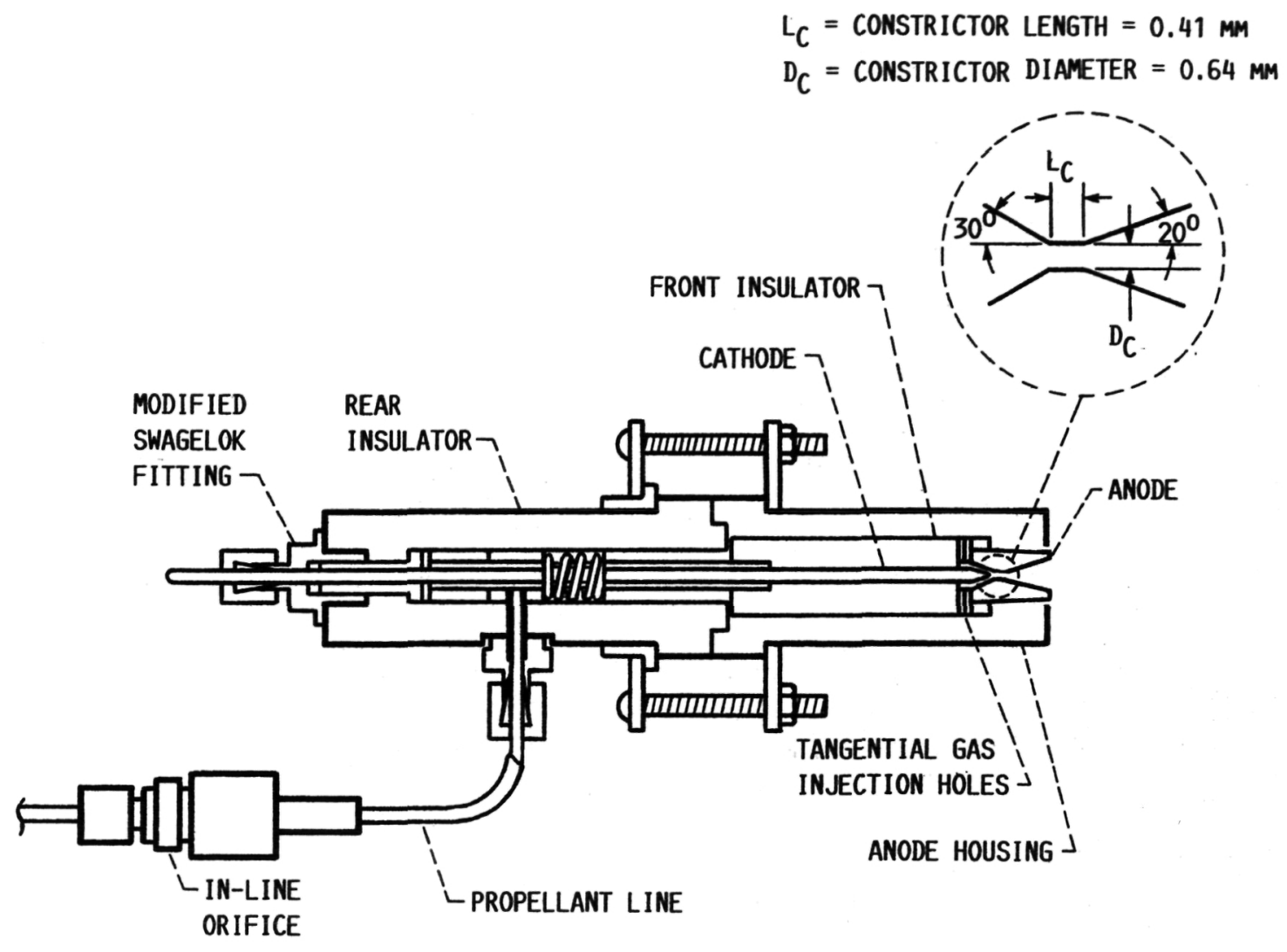

FIGURE 4. - LIFE TEST ARCJET. 


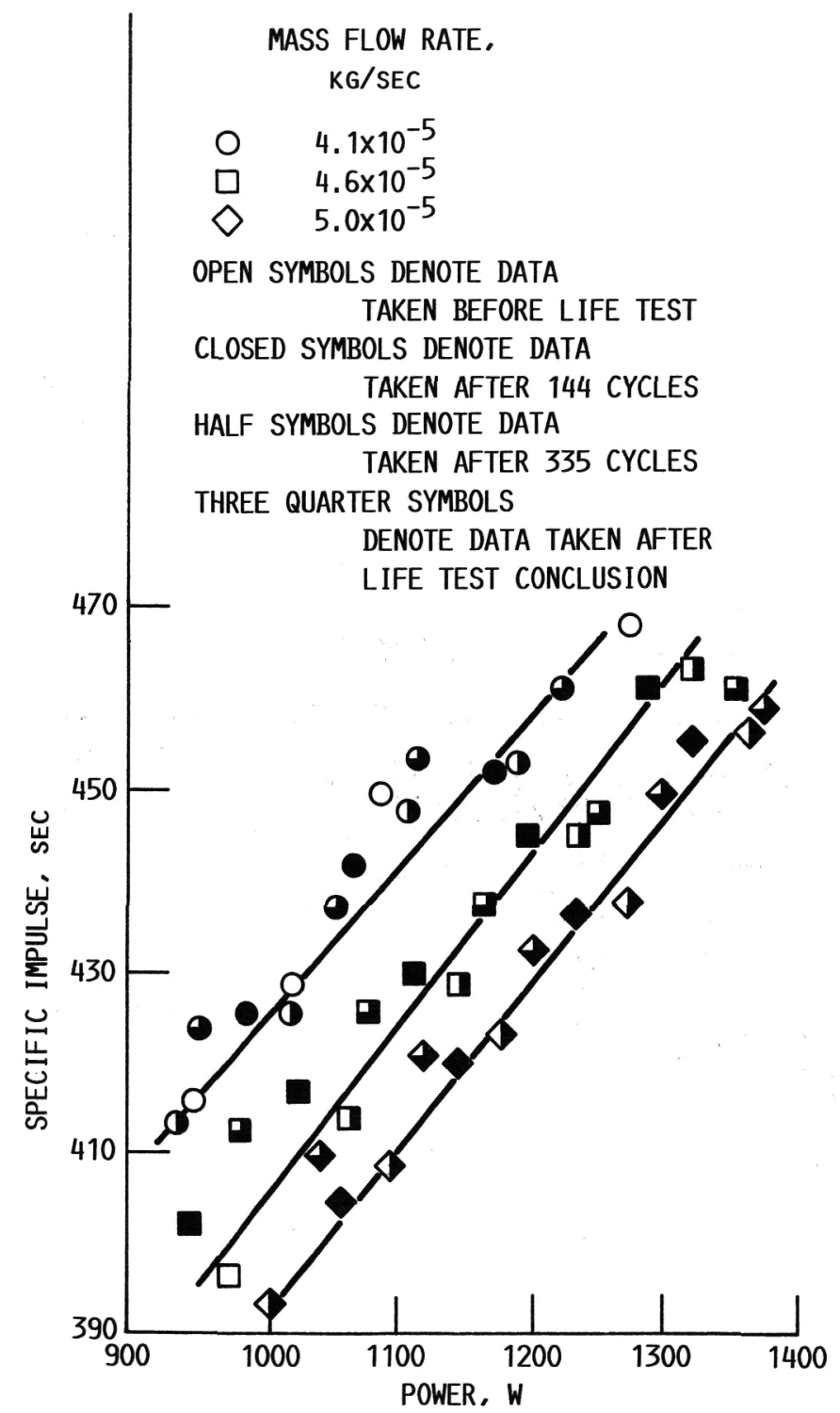

FIGURE 5. - PERFORMANCE DATA TAKEN BEFORE AND DURING LIFE TEST. 
ORIGNAE PAGE IS

OE POOR QUALITY
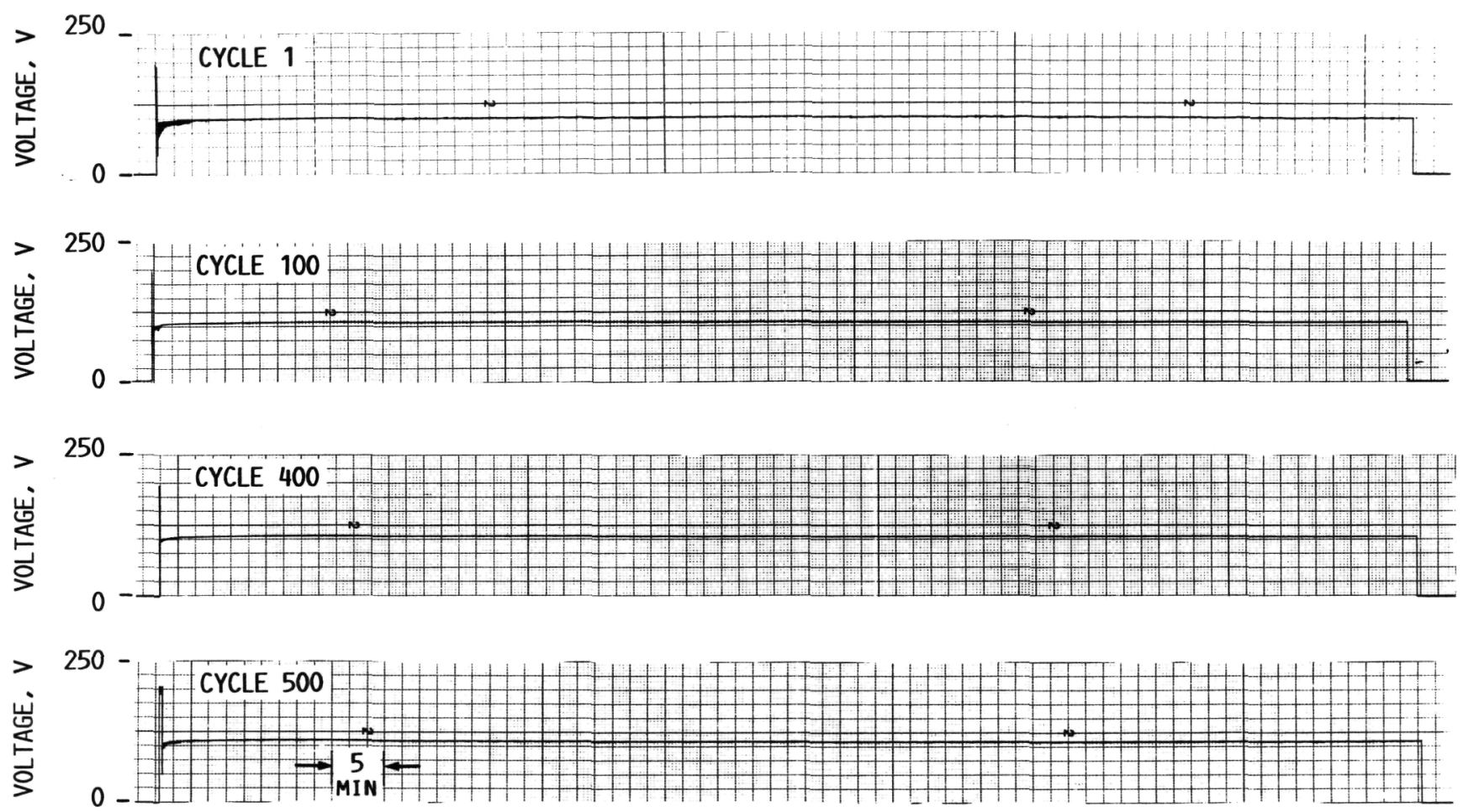

FIGURE 6. - TYPICAL ARCJET PERFORMANCE DURING 1000-HR LIFE TEST. 
CATHODE

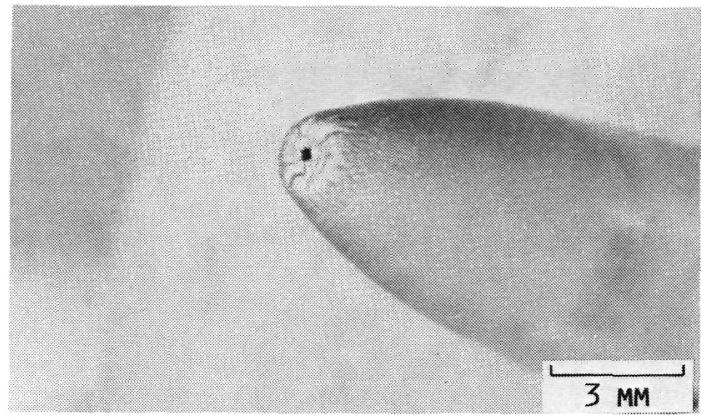

(a) CATHODE TIP.

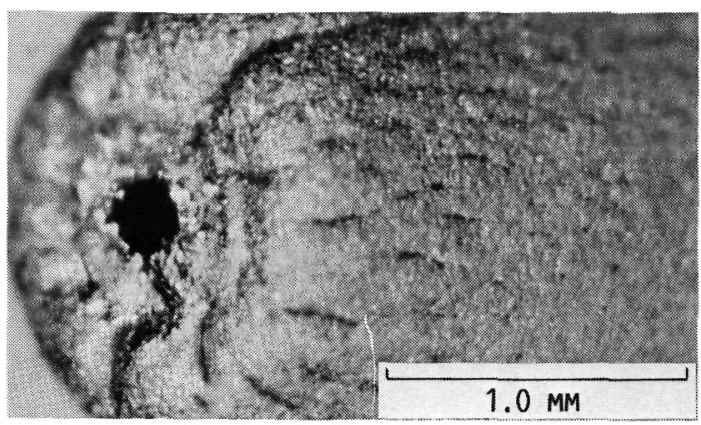

(b) CATHODE CENTER.

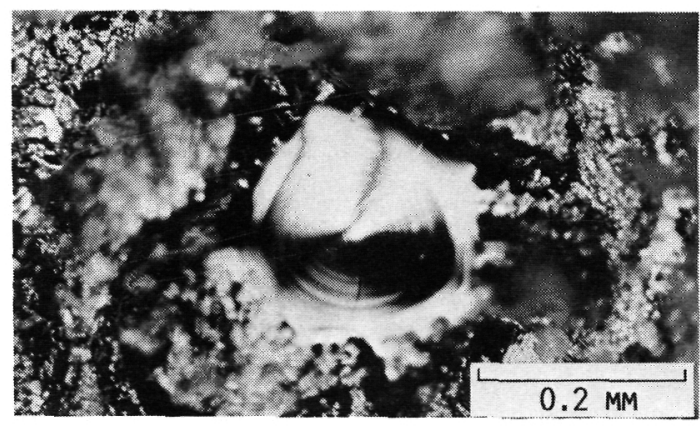

(c) MOLTEN POOL.
ANODE

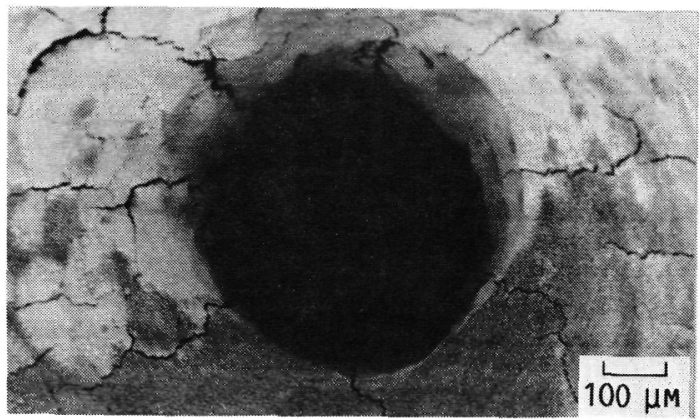

(d) CONVERGING SIDE OF NOZZLE.

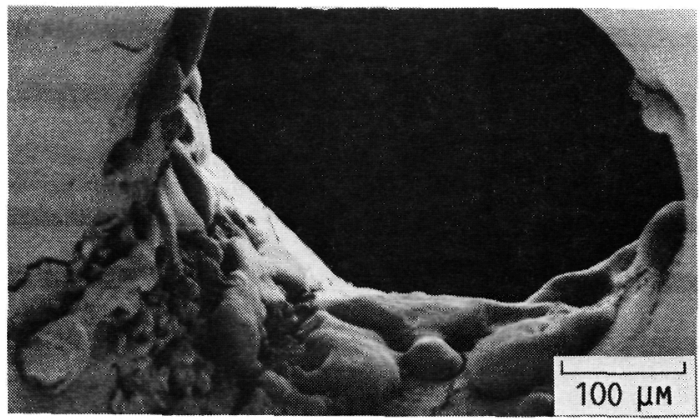

(e) DIVERGING SIDE OF NOZZLE.

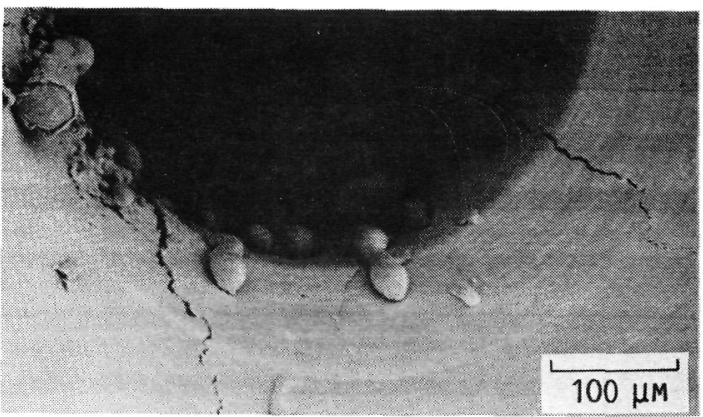

(†) DIVERGING SIDE OF NOZZLE.

FIGURE 7. - ELECTRODES FROM LIFE TEST. 
- FIRST OBSERVATION OF CORRECTED-THRUST DEPENDENCE ON FACILITY PRESSURE

- STANDARD PRESSURE-AREA CORRECTION NOT ADEQUATE FOR HEATED FLOW

- PERFORMANCE DEgRAdation DUE tO thermal LOSSES

- INDUSTRY INCORPORATINg theRMAL CORRECTIONS IN PERFORMANCE EVALUATIONS

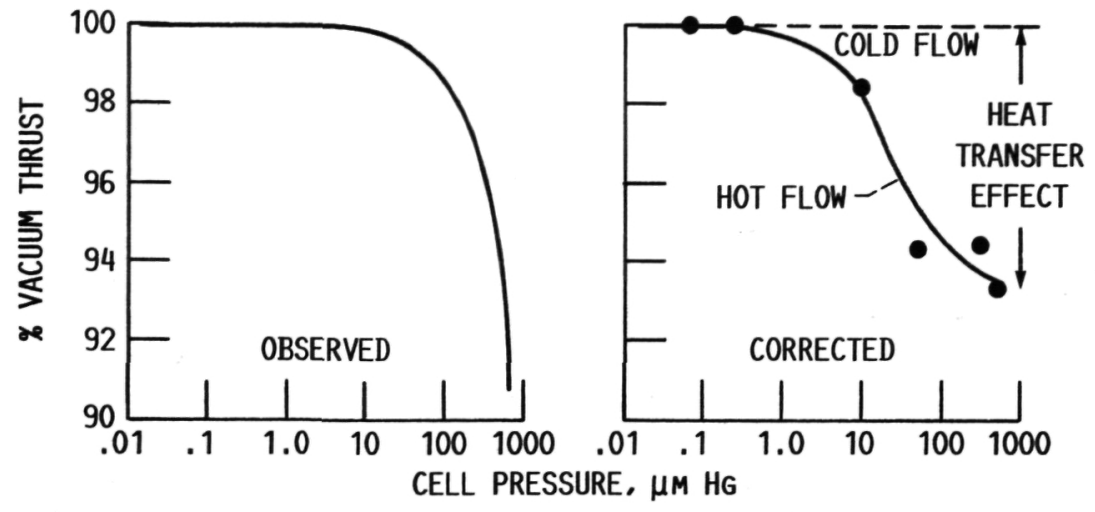

FIGURE 8. - FACILITY EFFECTS ON RESISTOJET PERFORMANCE.

- VORTEX BOILER CONCEPT DEFINED AND TESTED

- GAS/LIQUID SEPARATION ENHANCED

- EFFICIENT HEAT TRANSFER

- STABLE high-QUALITY STEAM GENERATION DEMONSTRATED

- Minimum SENSITIVITY TO ORIENTATION ("G") EFFECTS
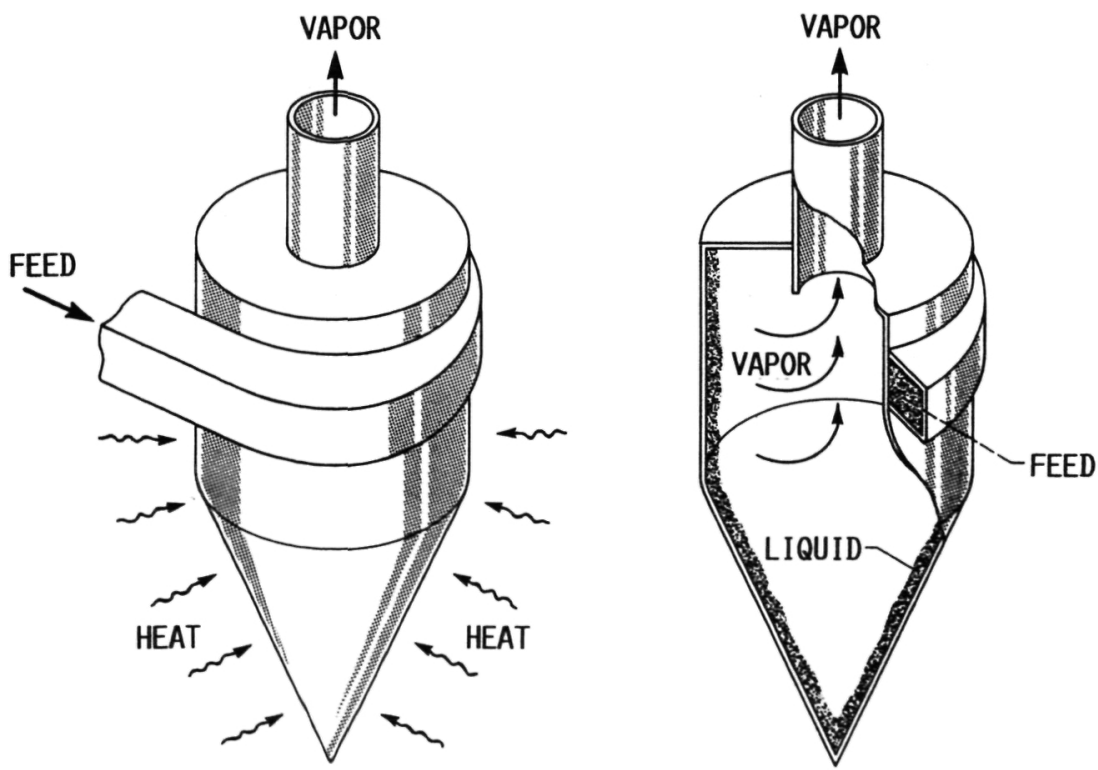

CD-11694-33

FIGURE 9.- CYCLONE STEAM GENERATOR. 


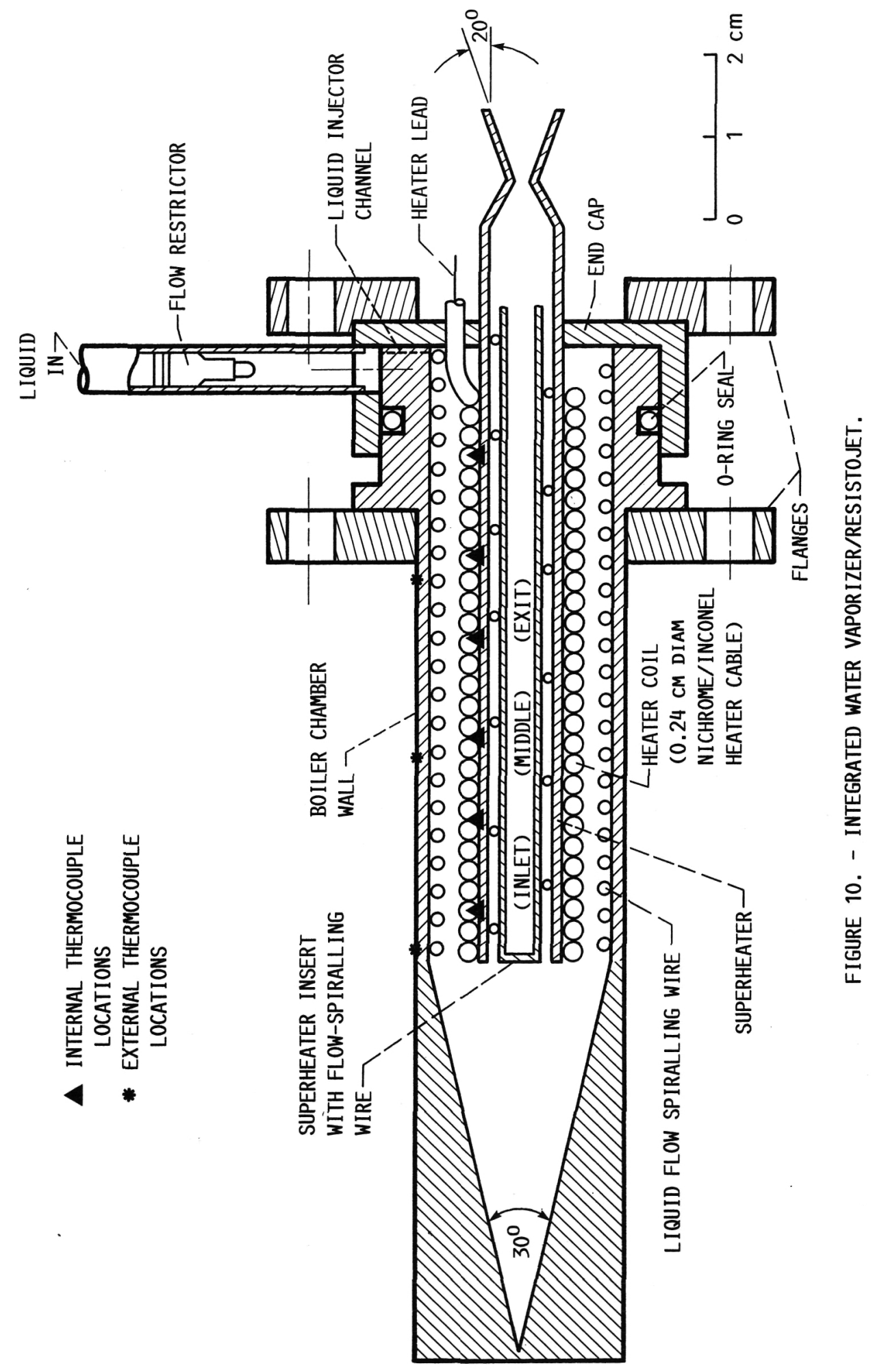




\section{ORIGINAL PAGE IS \\ OF POOR QUALITY.}

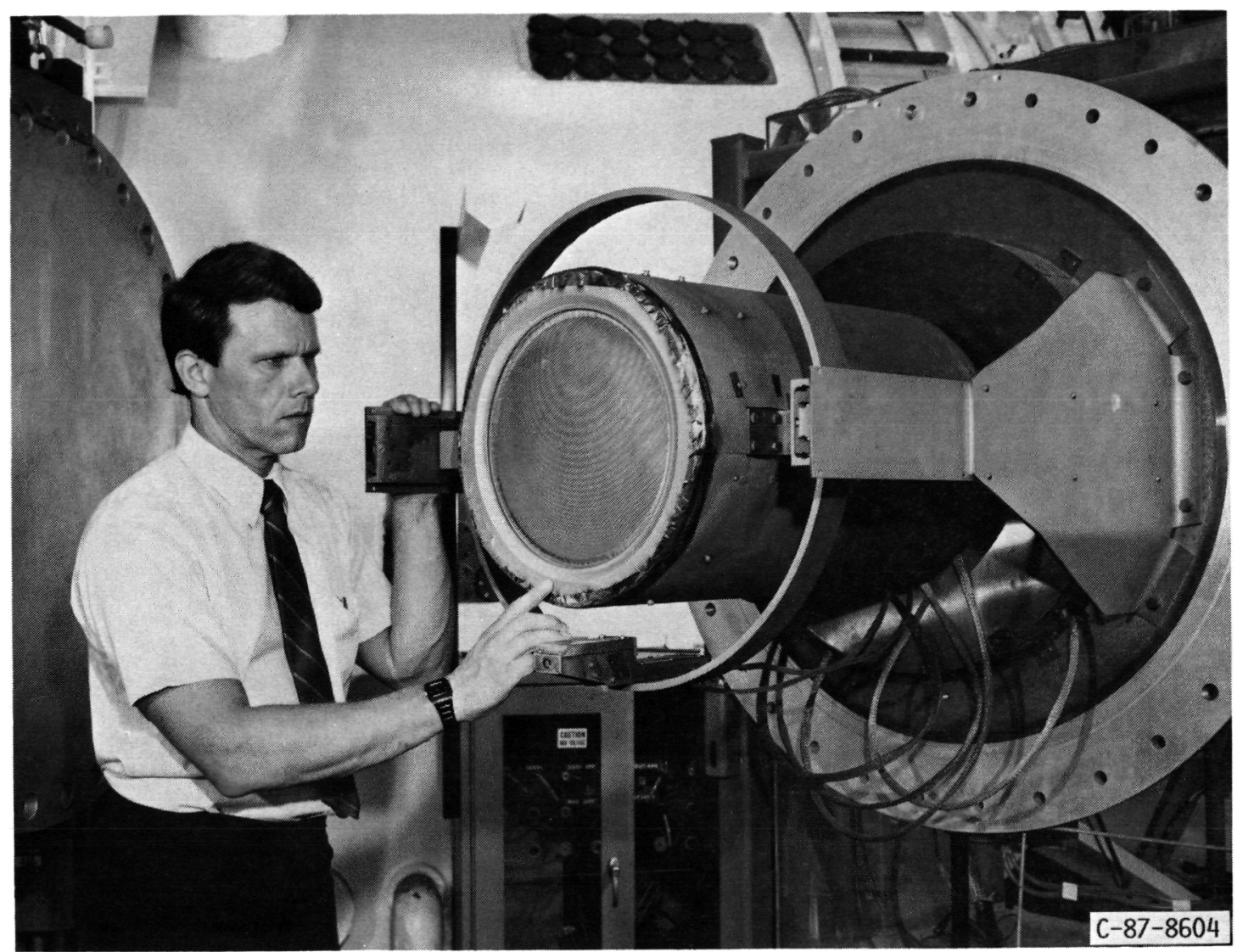

FIGURE 11. - $10 \mathrm{~kW}$ XENON THRUSTER. 


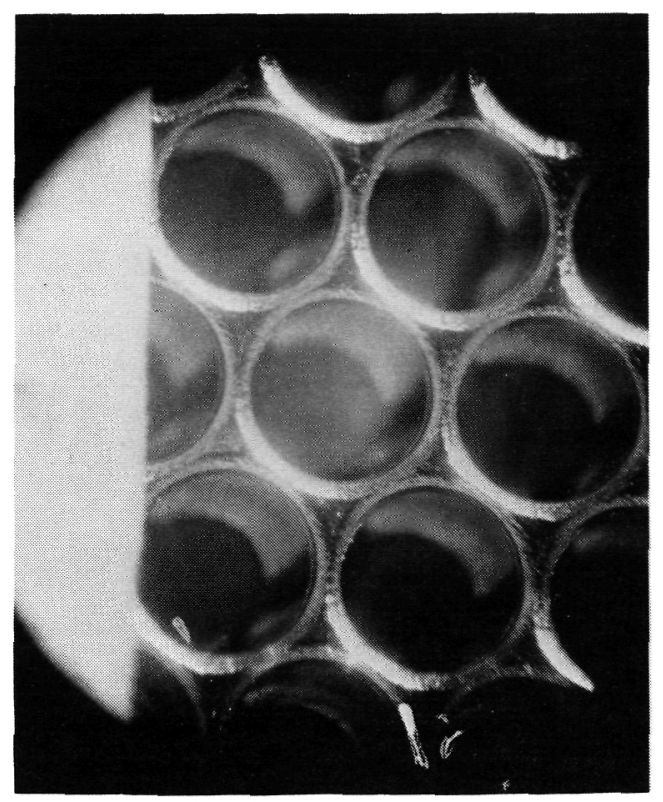

(a) UPSTREAM SIDE, BEFORE TEST.

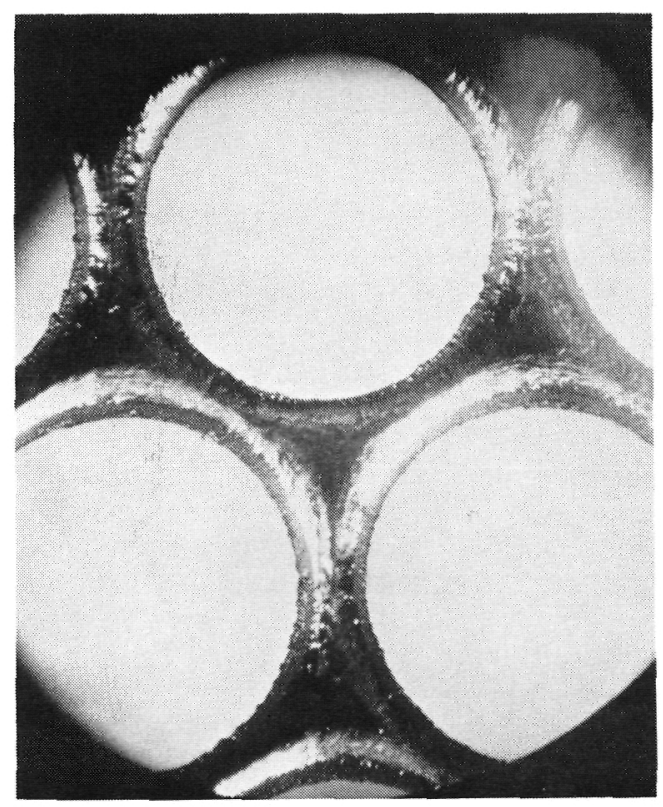

(c) UPSTREAM SIDE, AFTER TEST.

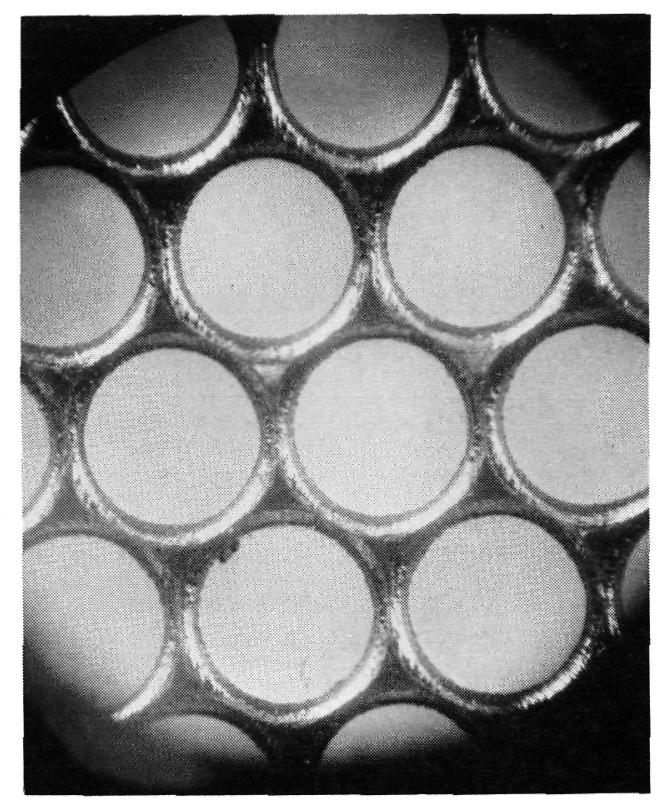

(b) UPSTREAM SIDE, AFTER TEST.

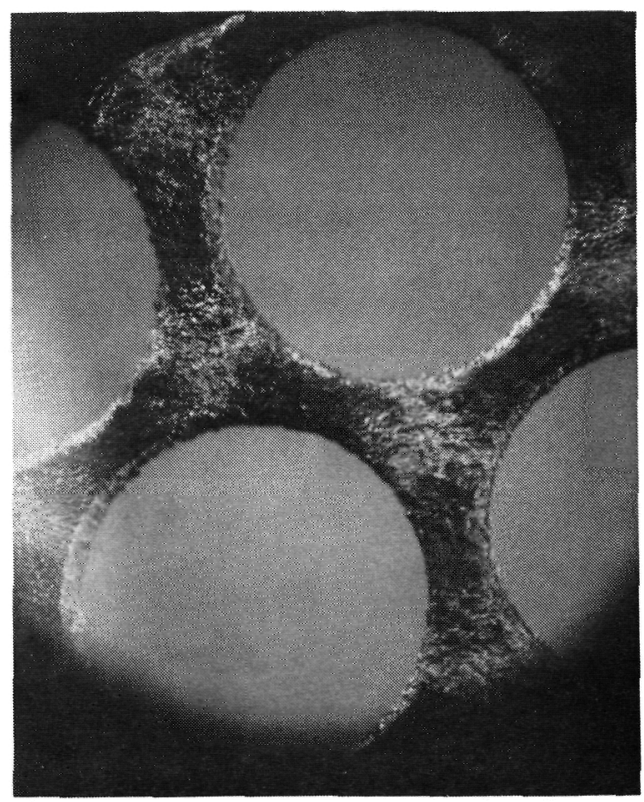

(d) DOWNSTREAM SIDE, AFTER TEST. FIGURE 12. - SCREEN GRID. 


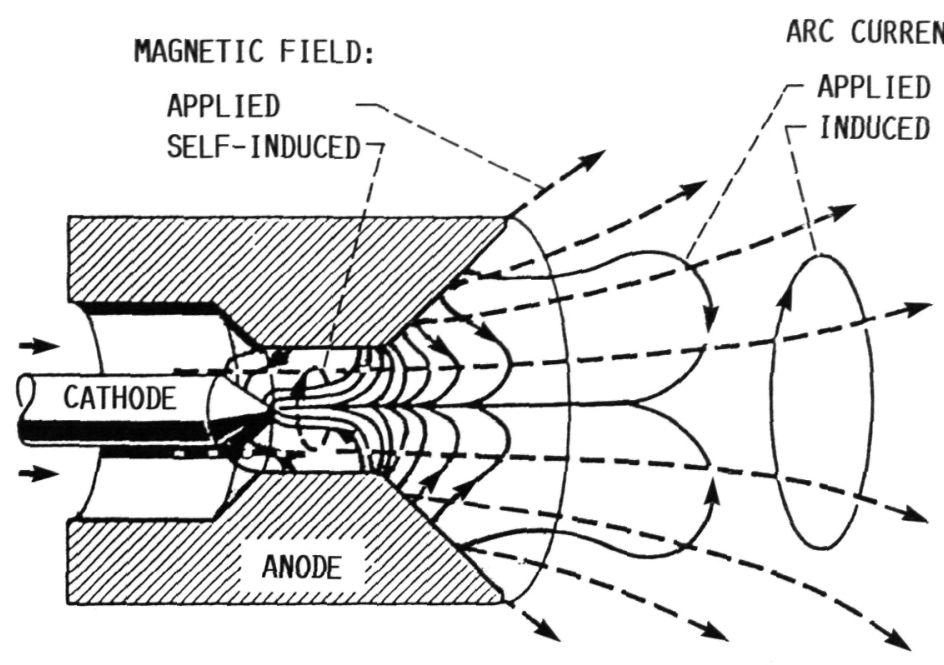

FIGURE 13. - MPD ARC THRUSTER CURRENTS AND FIELDS.

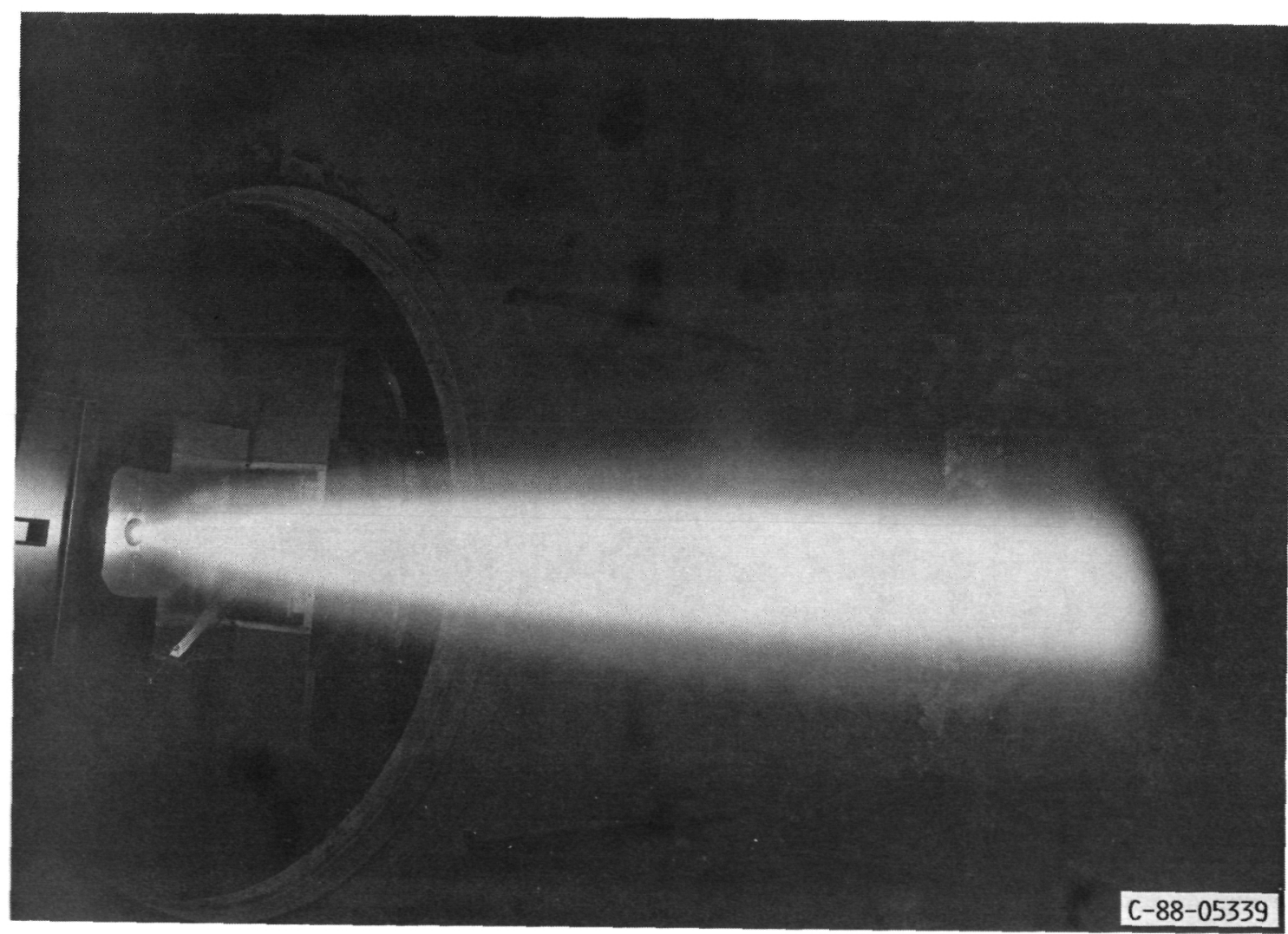

FIGURE 14. - MPD ARC THRUSTER OPERATING AT $102 \mathrm{~kW}$ INPUT POWER. 


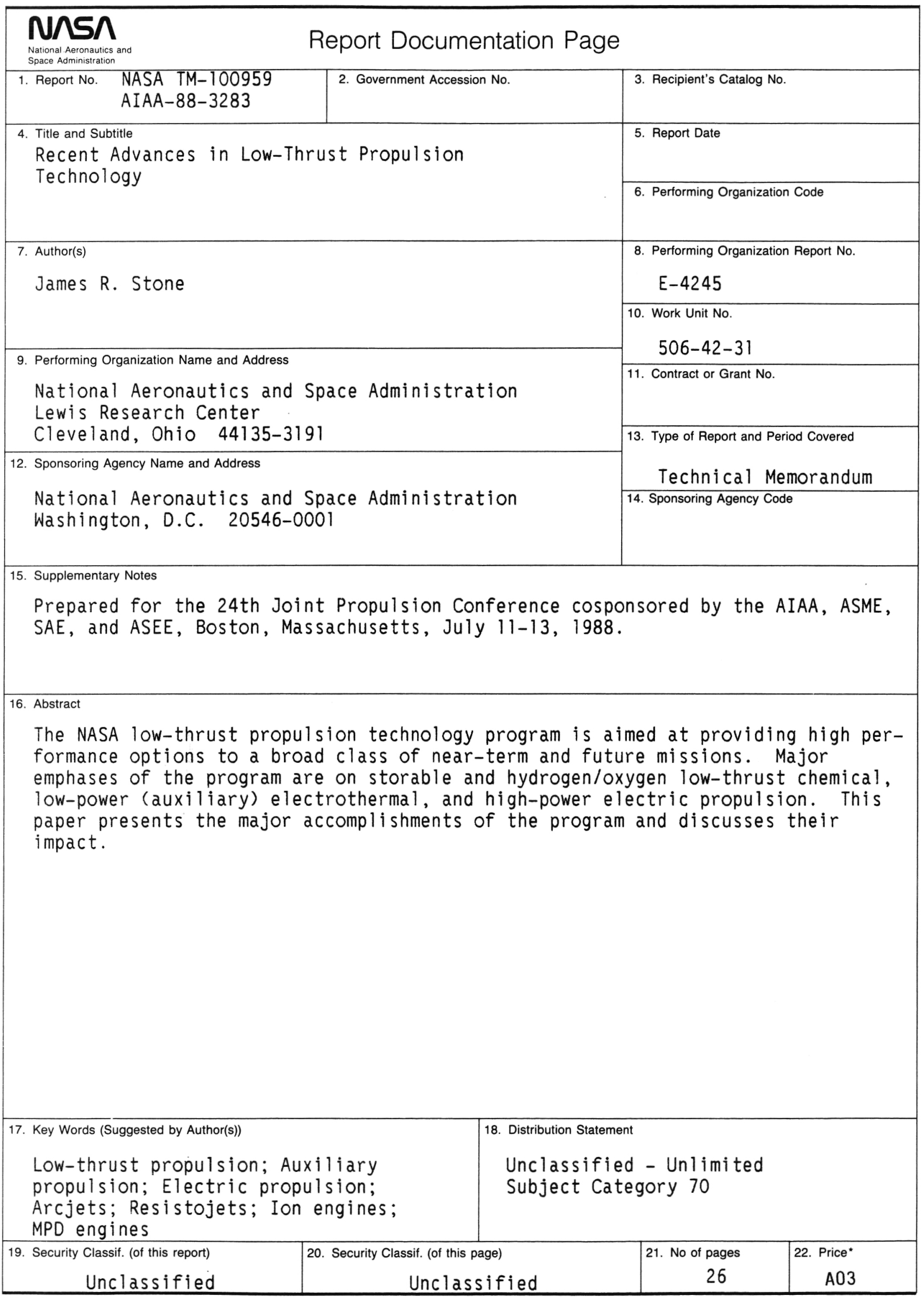


National Aeronautics and Space Administration

Lewis Research Center

Cleveland, Ohio 44135

Official Business

Penalty for Private Use $\$ 300$
FOURTH CLASS MAIL

ADDRESS CORRECTION REQUESTED

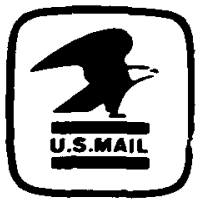

Postage and Fees Pa: Nar.onal Aeronautics ano Space Administratum NASA 451 